\author{
BAZALII V. V. ${ }^{1}$, BOICHUK I. V. ${ }^{1}$, LAVRYNENKO Yu. O. ${ }^{2}$, BAZALII H. H. ${ }^{2}$, \\ DOMARATSKYI Ye. O. ${ }^{1}$, LARCHENKO O. V. ${ }^{1}$ \\ ${ }^{1}$ SHEI "Kherson State Agricultural University", \\ Ukraine, 73006, Kherson, Stritenska str., 23,e-mail:i_boychuk@ukr.net \\ ${ }^{2}$ Institute of Irrigated Agriculture of NAAS of Ukraine, \\ Ukraine, 73483, Kherson, Naddniprianske village,e-mail: izz.ua@ukr.net \\ 凶i_boychuk@ukr.net
}

\title{
PROBLEMS AND PRODUCTIVITY OF WINTER WHEAT VARIETIES SELECTION WITH INCREASED ENVIRONMENTAL STABILITY
}

\begin{abstract}
Aim. The search of adaptive response peculiarities to adverse environmental factors is an important condition of development of varietal technologies and control of adaptive potential of winter wheat varieties. Methods. The studies were carried out in accordance with the field test methodology. The wheat varieties of different types of growing, different genetic and ecological origins were studied. Results. In our studies, plasticity index $\left(b_{i}\right)$ of most winter wheat varieties was close to one and higher under various growing conditions. The yield advantage of a number of varieties was mainly in favourable weather conditions, and in unfavourable conditions yields were low. Varieties that are more resistant to stressful conditions (Askaniis`ka, Kuialnyk, Klarisa, Driada) were characterised by relatively low response to changes of growing conditions, their regression factor was less than one and kept reducing, their resistance to unfavourable conditions were increased. Conclusions. If severe stress limits in environmental conditions are expected, it is necessary to grow and use the winter wheat varieties with increased stability of yielding capacity in selection (Khersonska bezosta, Khersonska 99, Znakhidka odes`ka, Askaniis`ka, Klarisa (facultative).

Keywords: winter wheat, plasticity, stability, yielding capacity.
\end{abstract}

Production of winter wheat significantly varies over the years, and in some years $(2000,2003)$ its production decreased by several times, mainly due to insufficient resistance of varieties to abiotic and biotic environmental factors. It is necessary to consider the opinion of academician Lytvynenko M.A. [1] that, prior to appropriate growing conditions, variety and seeds are one of the most available and effective means of stabilization of production of winter wheat grains, and each variety has its own set of yield limiting factors under stressful weather or technological situations.

Today, a new varietal policy for optimization of varietal peculiarities for conditions of their growing is required. A variety as a biological system is to be considered in the aspect of implementation of genetic potential in a specific ecological region [2-4].

Each new variety shall combine a number of hereditary factors that control various biological and economic characteristics. A special place is taken by the features that provide yield stability under changes of environmental conditions. This stability in time and space is determined by genetic mechanisms of homeostasis or created at the account of its own regulatory mechanisms [5].

Many terms, such as stability, plasticity, homeostaticity, general and specific adaptive ability, and others are used in foreign and domestic literature. There are cases when these terms are opposed to each other or are considered synonymous, and sometimes it seems that they are complementary. It partially refers to the terms "stability and plasticity" [3].

When using of one or another interpretation of the term, it is important to determine their biological essence so that their biological interpretation coincided. This understanding supposes that the genotype is stable and its implementation is resistant. It is characterised by a response to improvement or deterioration of environmental conditions. In the broad sense, such a genotype is considered stable if its growth is insignificantly influenced by environmental changes $[6,7]$.

\footnotetext{
${ }^{\circ}$ BAZALII V. V., BOICHUK I. V., LAVRYNENKO Yu. O., BAZALII H. H., DOMARATSKYI Ye. O., LARCHENKO O. V.
} 
In genetic sense, the plasticity can be understood as the degree of modification of characteristics that allows an organism to adapt to these conditions. In agronomic sense, it is the degree of distribution of variety in production [8].

A number of scientists [9-11] believe that plasticity is to be understood as selectionists understand it. Plasticity is to be understood as the ability of a variety to combine a sufficiently high yielding capacity with its stability under varying conditions, while genotypes with hyperreaction to growth conditions are to be considered sensitive to these conditions.

\section{Materials and methods}

Winter and alternative wheat varieties that were registered in the State Register of new varieties were taken as material of study. Their study at the state variety test plot was mainly based on the partial comparison of the "variety-X zone" interaction. It is preferably to introduce a methodology of comparison of ecological plasticity and stability of specific varieties to evaluate the degree of their response to improvement or deterioration of conditions over years and zones of cultivation [12]. The method of evaluation of stability and plasticity parameters according to the algorithm of Eberhart and Russel is the most general approach for this purpose [6]. It consists in the regression analysis of the grain yielding capacity, depending on the environmental index when the interaction of the "genotype of X condition" is considered to a certain extent.

\section{Results and discussion}

The results of studies of many scientists, including domestic ones [3], show that the features of resistance of genotype to unfavourable conditions are adequately reflected in the yield stability. At the same time winter wheat varieties with high yielding potential (9.0-12.0 t/ha) have different features of resistance. This means that there are real, although little, possibilities for further modification of wheat varieties for improvement of both productive and adaptive potentials. However, internal biological formation mechanisms of plants with such genetic status are still known insufficiently.

Each variety may have its own set of yield limiting factors under stressful situations. Low resistance to phytopathogens, drought, low negative and high positive temperatures refer to major yield limiting factors for many varieties. It is difficult to combine high yielding capacity and the indicated features in one genotype. Theoretical approaches for solution of this matter are few and all of them are general in nature.

Currently, methods for selection of valuable genotypes are developed much better than the methods of directional control of genotype variability. The performance of natural selection, depending on the environmental conditions, can significantly reduce the range of available adaptive genotype variability. Therefore, it is necessary to develop methods of adaptive selection that would allow or to some extent purposely supplement natural selection to form available genotype variability. We believe that it is possible to perform it under different growing conditions (different biocenotic relations, years with different climatic conditions, etc.). In this case, environment acts as a factor that not only sorts the genotypes according to their fitness, but also greatly determines the structure of hybrid populations in subsequent generations for the genotype. The modification variability can be useful in survival of genotypes and increase of their productivity. This is especially true for the resistance increase of the winter wheat plants to extreme environmental stress.

Most of varieties and forms of winter wheat that are developed during selection fall into disuse. However, it can be assumed that significant genotype variety of features, which have not been subjected for selection, lies behind phenotypic homogeneity. Therefore, if they are studied under different growing conditions, the genetic sources of new features can be revealed and wider opportunities for adaptive selection can be provided.

Our studies showed that hybridization within a single Southern-steppe ecotype allows to provide high yield of selection lines that have adaptive features at the same level with the best parental components of crossing, and some features are even better (Table 1).

In selection, it is important for corresponding biotypes to combine the important adaptive features of winter and drought tolerance in such a crossing cycle. Unfortunately, it is difficult to alter the yield potential of minor recombinations at once, including the case when at least one of the crossing components is classified as a highly productive genotype.

When forms of other ecotypes with local adaptive varieties are included into hybridization, it allows to make a significant reserve of genetic variability by many features. Significant recombinations with required parameters of plant height, yield and quality of grain are observed, but they 
Bazalii V.V., Boichuk I.V., Lavrynenko Yu.O., Bazalii H.H., Domaratskyi Ye.O., Larchenko O.V.

Table 1. Fitting efficiency of selective and valuable forms according the type of crossing, 2003-2017

\begin{tabular}{|c|c|c|c|c|c|}
\hline \multirow[b]{2}{*}{ Ecotype of varieties used in hybridization } & \multicolumn{5}{|c|}{$\begin{array}{l}\text { Frequency of biotypes according to characteris } \\
\text { tics, } \%\end{array}$} \\
\hline & 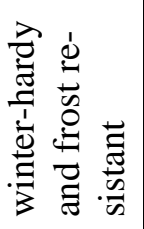 & 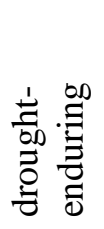 & 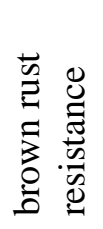 & 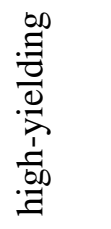 & 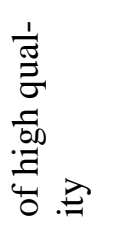 \\
\hline Southern-steppe / southern-steppe & 46.4 & 58.4 & 24.5 & 28.6 & 28.5 \\
\hline Southern-steppe / forest-steppe & 32.8 & 28.6 & 32.8 & 54.8 & 15.8 \\
\hline Southern-steppe / North-West & 28.9 & 10.6 & 18.4 & 8.4 & 10.4 \\
\hline Southern-steppe /West-European & 14.8 & 5.4 & 32.4 & 42.8 & 5.8 \\
\hline Forest-steppe / West-European & 10.4 & 3.6 & 26.8 & 52.8 & 7.2 \\
\hline
\end{tabular}

were mainly characterized by mediocre variants of adaptive features. Perhaps, increase of the frequency of recombinations in the system of ecologically distant crossings "destroys" the blocks of genes that control adaptive features, and especially the ones that affect the resistance to environmental extreme factors. It is important that the varieties of Southern - steppe origin as a crossing component had the least negative characteristics in the view of selection.

Table 1 shows that an increased yield of high-yielding forms is observed in most cases of ecologically distant crossings. However, sharp reduction of productivity is observed in many biotypes that have sharp positive deviations of individual components of productivity (the number of grains of spikelet, the weight of grains of spikelet and 1000 grains) under stressful conditions of the Southern Ukraine.

The expansion of programs of adaptive selection of winter wheat is slowed by the intensity of this process, therefore, the development of additional methods for determination of the morphobiotypic plasticity is required. In this regard, testing of new varieties and forms of winter wheat and hybrid populations at the early stages of selection under different growing conditions allows to predict the genetically possible stability of winter wheat biotypes.

The correlation analysis showed that practically there aren't any morpho-biological characteristic connected with the plasticity index so closely that it could be used as a criterion for secondary selection. However, further tests showed that the level of modification variability of the components of grain productivity and the overall yield under environmental factors are directly dependent on the modification of the "height of plants" characteristic.
On the grounds of this condition we carried out a secondary evaluation of the genotypes according to plasticity in variety testing and according to the type of informative selection ground in soils that contrasts in stress levels of environmental factors (density of plant stands, sowing terms, climatic conditions of research years), calculated the level of plasticity $\left(b_{i}\right)$ characteristics according to the environmental condition index.

The representativeness of the variability of plants that is ensured and detected under the influence of genotype and their interaction with environment. Our studies show that increase of seeding density revealed a decrease in the phenotypic variability of yield and increased adaptability of lowgrowing winter wheat varieties (Znakhidka odes`ka, Askaniis`ka, Klarisa). When the mediumgrowing varieties (Khersonska 99, Dryada 1, Yaroslavna, Kharus) were sown denser the plants lodged and it led to an increase in yield variability and a decrease of the adaptability parameters.

Forecasting of the yield variability of different winter wheat varieties within growing conditions is possible with the help of regression analysis that characterizes the average response of variety to change of environment, i.e. it determines their plasticity (Table 2).

The analysis of the obtained estimated data showed that winter wheat varieties Driada 1 , Antonivka, Kuialnyk, Znakhidka odes`ka, Solomiia, Klarisa responded to changes of growing conditions $\left(b_{i}=0.680-0.980\right)$ in a less degree comparing with other varieties. The varieties Yaroslavna, Kharus and alternative wheat varieties Lastivka, Zymoiarka, Khutorianka $\left(b_{i}=1.108-1.776\right)$ had the strongest response to changes of growth conditions. They are also characterised by the lowest stability of yield formation $\left(b_{i}{ }^{2}=10.04-16.08\right)$. 
Problems and productivity of winter wheat varieties selection with increased environmental stability

Table 2. Indicators of plasticity and stability of yield of winter wheat varieties under different growing conditions, 2007-2017

\begin{tabular}{|c|c|c|c|c|c|c|}
\hline \multirow{2}{*}{ Variety } & \multicolumn{3}{|c|}{ Yielding capacity, t/ha } & \multirow{2}{*}{$\begin{array}{l}\text { Range of } \\
\text { deviation, } \\
\mathrm{R}, \mathrm{hwt} / \mathrm{ha} \text {. }\end{array}$} & \multirow{2}{*}{$\begin{array}{l}\text { Regression } \\
\text { coefficient, } b_{i}\end{array}$} & \multirow{2}{*}{$\begin{array}{l}\text { Stabil- } \\
\text { ity in- } \\
\text { dex, } d^{2}\end{array}$} \\
\hline & $\min$ & $\mathrm{X}$ & $\max$ & & & \\
\hline Khersonska bezosta & 5.22 & 5.64 & 7.86 & 26.4 & 1.080 & 3.40 \\
\hline Khersonska 99 & 5.20 & 5.51 & 7.88 & 26.8 & 1.088 & 5.81 \\
\hline Driada 1 & 4.95 & 5.84 & 7.84 & 28.9 & 0.780 & 9.68 \\
\hline Kirena & 4.28 & 5.08 & 7.62 & 33.4 & 1.010 & 12.44 \\
\hline Yaroslavna & 4.89 & 5.48 & 8.04 & 31.5 & 1.110 & 10.04 \\
\hline Antonivka & 4.42 & 5.41 & 7.46 & 30.4 & 0.980 & 6.90 \\
\hline Kuialnyk & 4.73 & 5.14 & 7.41 & 26.8 & 0.880 & 6.19 \\
\hline Znakhidka odes`ka & 4.60 & 6.21 & 7.82 & 30.2 & 0.940 & 8.16 \\
\hline Kharus & 3.61 & 4.64 & 6.92 & 34.8 & 1.408 & 14.94 \\
\hline Askaniis`ka * & 5.84 & 6.88 & 7.92 & 20.8 & 0.690 & 2.44 \\
\hline Lastivka * & 2.39 & 4.46 & 6.41 & 40.2 & 1.776 & 14.21 \\
\hline Solomiia ${ }^{*}$ & 3.83 & 5.21 & 7.64 & 38.1 & 0.980 & 1.08 \\
\hline Klarisa $^{*}$ & 4.90 & 5.28 & 7.84 & 38.2 & 0.874 & 8.06 \\
\hline Zymoiarka $^{*}$ & 2.96 & 4.70 & 6.44 & 34.8 & 1.408 & 16.08 \\
\hline Khutorianka ${ }^{*}$ & 3.05 & 4.63 & 6.21 & 31.6 & 1.108 & 14.90 \\
\hline
\end{tabular}

Note. *-2011-2017.

The largest range of deviation (R) under different growing conditions was shown by winter wheat varieties Yaroslavna, Kirena (3.15-3.48 tons/ha) and alternative varieties Kharus, Khutoryanka, Zymoiarka, Klarisa, Solomiia, Lastivka (3.16-4.02 t/ha). Under maximum yield of the first two winter wheat varieties $-7.62-8.04 \mathrm{t} /$ ha such a yield deviation shows high potential possibilities of varieties, but they are to be used in production carefully as in extreme conditions they can cause significant losses of yields.

Considering changes of weather conditions in recent years, significant warming in autumn period, alternative wheat varieties (Lastivka, Klarisa, Zymoiarka, Khutoryanka) are to be grown during later sowing time (the second - the third decade of November) and at the area under spring crops (February periods, I - II decade of March) as crops for the resowing of winter wheat varieties that were damaged during winter.

The tasks of adaptive selection can be solved if the methods for studying the plasticity of genotypes of plants at early stages of selection are developed and varieties and forms of winter wheat that are identified according to these characteristics are included.

It is known that the total productivity of a variety is formed as a result of compensatory relation- ships of the productivity components. Therefore, during selection it is necessary to identify characteristics for environmental resistance among overall structure of components. These characteristics are more responsible for constant increase of yielding capacity and have low modification variability.

We stated that formation of actual yielding capacity of winter wheat biotypes is established unclearly under various growing conditions. Therein, the distribution of the influence of selective characteristics was diametrically opposed in some cases in terms of the growing conditions and morphostructural features of genotype architectonics.

Therefore, the problems of adaptive selection of winter wheat are to be solved from the perspective of organization of selection process (finding, storage, identification and usage of appropriate genetic sources) and closely related systems of variety testing with elements of varietal agrotechnics.

\section{Conclusions}

1. During identification of varieties and forms of various types of high yielding wheat with increased adaptive potential, it is necessary to carry out stepwise evaluation under different growing conditions. 
2. Application of the method of evaluation of plasticity and stability parameters, suggested by Eberhart and Russell, allowed to distribute wheat varieties of different types of development according to response the environmental conditions. It is necessary to grow plastic varieties of wheat with increased yield stability (Khersonska bezosta, Khersonska 99, Nakhodka Odesa, Askaniis`ka, Klarisa) if severe stress limits are expected under environmental conditions.

\section{References}

1. Lytvynenko M.A. Theoretical fundamentals and methods of selection of winter soft wheat for increasing the adaptive potential for the conditions of the Steppe of Ukraine: abstract of doct. diss. Kyiv, 2001. 46 p. [in Ukrainian] / Литвиненко М.A. Теоретичні основи та методи селекції озимої м'якої пшениці на підвищення адаптивного потенціалу для умов Степу України: автореферат докторської дисертації. К., 2001. 46 с.

2. Lyfenko S.P., Lytvynenko M.A. Achievements in selection of soft winter wheat. Vistnyk ahrarnoi nauky. 2000. No. 12. P. 1320. [in Ukrainian] / Лифенко С.П., Литвиненко М.А., Досягнення в селекції пшениці озимої м'якої. Вісник аграрної науки. 2000. № 12. C. 13-20.

3. Bazalii V.V. Principles of adaptive selection of winter wheat in the zone of Southern steppe. Kherson: Ailant Publ., 2004. 224 p. [in Ukrainian] / Базалій В.В. Принципи адаптивної селекції озимої пшениці в зоні Південного Степу. Херсон: Айлант, 2004. 224 c.

4. Lykhochvor V.V., Petrychenko V.F. Vegetation. Modern intensive technologies of growing of main crops. Lviv: SPF "Ukrainian technologies" Publ., 2006. 730 p. [in Ukrainian] / Лихочвор В.В., Петриченко В.Ф. Рослинництво. Сучасні інтенсивні технології вирощування основних польових культур. Львів: НВФ «Українські технології», 2006. 730 с.

5. Zhuchenko A.A. Gene-environment fundamentals of adaptive system of plant selection. Selection and seed development. 1999. No. 4. P. 5-16. [in Russian] / Жученко А.А. Эколого-генетические основы адаптивной системы селекции растений. Ceлекиия и семеноводство. 1999. № 4. С. 5-16.

6. $\quad$ Eberhart S.N., Russle W.A. Stability parameters for comparing varieties. Crop. Sci. 1966. Vol. 6, No. 1. P. 36-40.

7. Tai G.G. Genotypic Stability Analysis and Its Application to Potato Regional Trials. Crop. Sci. 1971. Vol. 11, No. 2. P. 184-190.

8. Lytyn P.P. Interaction "genotype-environment" in genetic selective researches and methods of its study. In: Matters of selection and evaluation of selective materials. Kyiv, 1980. P. 63-92. [in Russian] / Литун П.П. Взаимодействие генотип-среда в генетических селекционных исследованиях и способы его изучения. В сб.: Проблемы отбора и оценки селекционного материала. К.: Наукова думка, 1980. С. 63-92.

9. Martynov S.P. Evaluation of environmental plasticity of crop varieties. Agricultural biology. 1983. No. 3. P. 124-128. [in Russian] / Мартынов С.П. Оценка экологической пластичности сортов сельскохозяйственных культур. Сельскохозяйственная биология. 1989. № 3. С. 124-128.

10. Hrabovets A.I., Fomenko M.A. Selection for increase of environmental plasticity of winter wheat as one of the most important conditions in development of high yielding varieties. Selection and seed production. Kharviv, 2013. No. 103. P. 15-23. [in Russian] / Грабовец А.И., Фоменко М.А., Селекция на усиление экологической пластичности озимой пшеницы одно из важнейших условий при создании високо продуктивных сортов. Селекція $і$ насінництво. Харків, 2013. Вип. 103. C. $15-23$.

11. Lytvynenko M.A., Lyfenko S.P., Yeryniak M.I. Winter wheat varieties of steppe ecotype undergo extreme weather conditions better. Seed production. 2013. No. 9. P. 14-18. [in Ukrainian] / Литвиненко М.А., Лифенко С.П., Сриняк М.I. Сорти озимої м'якої пшениці степового екотипу краще переносять екстремальні погодні умови. Насінництво. 2013. № 9. C. 14-18.

12. Bushulian O.V., Stelmakh A.F., Lamari N. P., Fait V.I. Genotype response and yield stability of chickpea varieties (Cicer arietinuv L.) during years of research. Factors in experimental evolution of organisms. 2018. Vol. 23. P. 35-39. [in Ukrainian] / Бушулян О.В., Стельмах А.Ф., Ламарі Н.П., Файт В.І. Генотипова реакція та стабільність урожаю сортів нуту (Сicer arietinuv L.) за роками випробування. Фактори експериментальної еволюиії організмів. 2018. Т. 23. С. 35-39.

БАЗАЛІЙ В. В. ${ }^{1}$, БОЙЧУК І. В. ${ }^{1}$, ЛАВРИНЕНКО Ю. О. ${ }^{2}$, БАЗАЛІЙ Г. Г. ${ }^{2}$, ДОМАРАЦЬКИЙ Є. О. ${ }^{1}$, ЛАРЧЕНКО О. В. ${ }^{1}$

${ }^{l}$ ДВНЗ «Херсонський державний аграрний університет»,

Украӥна, 73006, м. Херсон, вул. Стрітенська, 2, е-таil: i_boychuk@ukr.net

${ }^{2}$ Інститут зрошуваного землеробства НААН України,

Україна, 73483, м. Херсон, смт. Наддніпрянське, е-таil: izz.иа@иkr.net

\section{ПРОБЛЕМИ І РЕЗУЛЬТАТИВНІСТЬ СЕЛЕКЦІї СОРТІВ ПШЕНИЦІ ОЗИМОЇ 3 ПІДВИЩЕНОЮ ЕКОЛОГІЧНОЮ СТАБІЛЬНІСТЮ}

Mema. 3'ясування особливостей адаптивних реакцій на несприятливі чинники зовнішнього середовища $\epsilon$ важливою умовою розробки сортових технологій і управління адаптивним потенціалом сортів пшениці м'якої озимої. Методи. Дослідження проводили згідно методики польового досліду. В дослідах використовували сорти пшениці різного типу розвитку, різного генетичного і екологічного походження. Результати. У наших дослідженнях за різних умов вирощування у більшості сортів пшениці озимої показник пластичності $\left(\mathrm{b}_{\mathrm{i}}\right)$ був близький до одиниці і вище. Перевага ряду сортів за врожайністю була в основному у сприятливі за погодними умо- 
вами роки, а в несприятливі знижувалась. Більш стійкі до стресових ситуацій сорти (Асканійська, Куяльник, Кларіса, Дріада) відрізнялись відносно низькою реакцією на зміну умов вирощування, коефіцієнт регресії у них менше одиниці, із подальшим зниженням його, стійкість до несприятливих умов збільшувалась. Висновки. У випадку очікування сильних стресових лімітів за умов зовнішнього середовища необхідно вирощувати і використовувати в селекційній роботі пластичні сорти пшениці озимої з більш високою стабільністю врожайності (Херсонська безоста, Херсонська 99, Знахідка одеська, Асканійська, Кларіса (дворучка).

Ключові слова: пшениця озима, пластичність, стабільність, урожайність. 